\title{
IRF7 Gene
}

National Cancer Institute

\section{Source}

National Cancer Institute. IRF7 Gene. NCI Thesaurus. Code C128881.

This gene plays a role in the modulation of the innate immune response against DNA and RNA viruses. 